\title{
Mucin secretion is modulated by luminal factors in the isolated vascularly perfused rat colon
}

\author{
A Barcelo, J Claustre, F Moro, J-A Chayvialle, J-C Cuber, P Plaisancié
}

\begin{abstract}
Background-Mucins play an important protective role in the colonic mucosa. Luminal factors modulating colonic mucus release have been not fully identified.
\end{abstract}

Aim-To determine the effect of some dietary compounds on mucus discharge in rat colon.

Methods-An isolated vascularly perfused rat colon model was used. Mucus secretion was induced by a variety of luminal factors administered as a bolus of $1 \mathrm{ml}$ for 30 minutes in the colonic loop. Mucin release was evaluated using a sandwich enzyme linked immunosorbent assay supported by histological analysis.

Results-The three dietary fibres tested in this study (pectin, gum arabic, and cellulose) did not provoke mucus secretion. Luminal administration of sodium alginate (an algal polysaccharide used as a food additive) or ulvan (a sulphated algal polymer) induced a dose dependent increase in mucin discharge over the concentration range $1-25 \mathrm{mg} / 1$ ( $\mathrm{p}<0.05$ for 25 $\mathrm{mg} / 1$ alginate and $\mathrm{p}<0.05$ for 10 and $25 \mathrm{mg} / 1$ ulvan). Glucuronic acid and galacturonic acid, which are major constituents of a variety of fibres, produced significant mucin secretion $(p<0.05)$. Hydrogen sulphide and mercaptoacetate, two sulphides produced in the colonic lumen by microbial fermentation of sulphated polysaccharides, did not modify mucin secretion. Among the short chain fatty acids, acetate (5-100 $\mathrm{mM}$ ) induced a dose dependent release of mucus $(p<0.05$ for $100 \mathrm{mM}$ acetate). Interestingly, butyrate at a concentration of $5 \mathrm{mM}$ produced colonic mucin secretion $(p<0.05)$, but increasing its concentration to $100 \mathrm{mM}$ provoked a gradual decrease in mucus discharge. Propionate (5-100 $\mathrm{mM}$ ) did not induce mucin release. Several dietary phenolic compounds (quercetin, epicatechin, resveratrol) did not provoke mucus discharge.

Conclusions-Two algal polysaccharides (alginate and ulvan), two uronic acids (glucuronic acid and galacturonic acid), and the short chain fatty acids acetate and butyrate induce mucin secretion in rat colon. Taken together, these data suggest that some food constituents and their fermentation products may regulate the secretory function of colonic goblet cells. (Gut 2000;46:218-224)
Keywords: mucin secretion; colon; dietary fibres; algal fibres; short chain fatty acids; sulphides

Intestinal mucins are high molecular mass glycoproteins which form a highly hydrated mucus gel coating the epithelial surface of the intestinal tract. ${ }^{1}$ Secreted by goblet cells, intestinal mucins are involved in a variety of cytoprotective functions against a number of hazards including mechanical insults, colonisation by pathogenic bacteria and their toxins, luminal proteases arising from bacterial and mucosal cells, and potential carcinogens. ${ }^{2}$

As mucins play a key role in the protection of the underlying epithelium, any quantitative change in mucus secretion may modify this defensive barrier and have important physiological implications. ${ }^{34}$ In particular, the interactions of dietary components with the secretory activity of goblet cells could represent new interesting possibilities for the manipulation of this important protective function. However, our knowledge of dietary factors that control the release of intestinal mucus is limited. Previous studies have simply shown by ultrastructural, ${ }^{56}$ autoradiographic, ${ }^{7}$ and enzyme linked immunosorbent assay (ELISA) techniques $^{89}$ that dietary supplementation with fibres increases the secretory activity of intestinal goblet cells. However, the short term effect of dietary fibres on colonic mucus secretion was not directly examined. Besides dietary fibres, a variety of algal polysaccharides are also found in human food as additives. ${ }^{10}$ These polysaccharides exhibit several unusual structural and chemical properties, especially the presence of sulphated groups (carrageenans). ${ }^{11}$ The physiological effects of these algal fibres on mucus secretion have not yet been investigated.

The effects of fibres, as observed in vivo on mucus cells, may be either direct or indirect, through the end products of their degradation by bacteria. Short chain fatty acids, which play important physiological roles in the colon, are the major products of colonic fermentation. ${ }^{12-14}$ Other components such as sulphides are also produced from sulphated fibres on degradation by colonic bacteria. ${ }^{15} 16$ Nothing is known about the influence of these end products on goblet cell secretory activity.

Several non-nutritive constituents such as polyphenols are also contained in a variety of fruits and vegetables. Dietary phenolic compounds seem to exert several pharmacological effects such as antioxidative and anticarcinogenic ones. ${ }^{17-19}$ Whether these compounds are involved in the regulation of colonic mucus secretion was therefore tested. 
It thus appears that colonic goblet cells may be under the control of numerous primary or secondary luminal factors, which makes the interpretation of most results gathered from in vivo experiments difficult. The present study was thus undertaken to investigate further the discharge of colonic goblet cells in response to several compounds occurring at the apical side of the goblet cells. For this purpose, the isolated vascularly perfused rat colon was used. This model provides a unique opportunity to study the secretion of mucus in response to well defined luminal stimuli in a manner that eliminates the influences potentially encountered in vivo. The polarised mucus cells may be thus submitted to specific stimulation with fibres or products of carbohydrate fermentation. The discharge of mucus was evaluated by a sandwich ELISA and histological analysis.

\section{Materials and methods \\ MATERIALS}

Bovine serum albumin was purchased from Biovalori (Cassens, France). Hyperamine 25, a mixture of amino acids, was obtained from Braun Medical (Boulogne, France). The following reagents were purchased from Sigma (Saint Quentin-Fallavier, France): cellulose, pectin, gum arabic, carrageenin iota, carrageenin kappa, and carrageenin lambda, fucoidan, glucuronic acid, galacturonic acid, $n$-butyrate, acetate, propionate, resveratrol, quercetin, epicatechin, sodium mercaptoacetate, sodium hydrogen sulphide, and dithiothreitol. Alginic acid sodium salt was purchased from Fluka (Saint Quentin-Fallavier, France). Ulvan (a new source of dietary fibre extracted from green seaweed) was kindly provided by $\mathrm{C}$ Cherbut (INRA, Nantes, France). Microtitre plates (NUNC-Immunoplate) were obtained from Polylabo (Paul block \& cie, Strasbourg, France).

\section{SURGICAL PREPARATION}

The operative procedure to prepare an isolated vascularly perfused rat colon was performed as previously described..$^{20}$ Briefly, male Wistar rats (250-350 g), purchased from Le Centre d'Elevage Dépré (Saint Doulchard, France), were anaesthetised with sodium pentobarbital (50 $\mathrm{mg} / \mathrm{kg}$, intraperitoneally). The proximal and transverse colons were freed from their visceral fixations. The ileocolic veins and arteries were tied. Both ends of the colonic loop (10 $\mathrm{cm}$ in length) were then fitted with Silastic tubing. A metal cannula and a Silastic cannula were then quickly inserted into the superior mesenteric artery and portal vein respectively. Arterial perfusion was started immediately at a rate of $2.5 \mathrm{ml} / \mathrm{min}$ with Krebs-Henseleit buffer (2 $\mathrm{mM} \mathrm{CaCl}_{2}, 6 \mathrm{mM} \mathrm{KCl}, 3.18 \mathrm{mM} \mathrm{NaH}_{2} \mathrm{PO}_{4}$, $104 \mathrm{mM} \mathrm{NaCl}, 1 \mathrm{mM} \mathrm{MgSO}, 41.6 \mathrm{mM}$ $\mathrm{NaHCO}_{3}, \mathrm{pH} 7.4$ ) containing $25 \%$ washed bovine erythrocytes, 3\% bovine serum albumin, $5 \mathrm{mM}$ glucose, and $1 \%(\mathrm{v} / \mathrm{v})$ hyperamine 25. The perfusion pressure, continuously recorded with a mercury manometer, ranged from 55 to $75 \mathrm{~mm} \mathrm{Hg}$. The colonic lumen was flushed out with prewarmed isotonic saline and then with air, and both ends of the intestinal loop were ligated. The preparation was then removed and transferred to a bath containing isotonic saline at $37^{\circ} \mathrm{C}$.

\section{EXPERIMENTAL PROTOCOL}

The experiments consisted of a 10 minute equilibration period, followed by a 30 minute period of stimulation. Immediately after the equilibration period, the loops were filled by injection with $1.0 \mathrm{ml}$ of prewarmed isotonic saline (control groups) or with $1 \mathrm{ml}$ of luminal factors at $37^{\circ} \mathrm{C}$. All luminal agents to be tested were prepared freshly before the stimulations started. The $\mathrm{pH}$ of each luminal compound was adjusted to $7-7.5$, and the osmolarity was increased when required to $300 \mathrm{mosmol} / \mathrm{kg}$ by the addition of appropriate amounts of $\mathrm{NaCl}$. Control data were obtained from separate groups of animals.

At the end of the experimental period, loops were cut at both ends. Fluid content was collected. To remove the mucus adherent to the mucosal surface, loops were carefully emptied by manual massage, subsequently flushed with $15-20 \mathrm{ml}$ air, and drained. Luminal contents (fluid contents + adherent mucus gel) were weighed, sonicated, and frozen at $-20^{\circ} \mathrm{C}$ for subsequent determination of mucin-like immunoreactivity and luminal DNA content. The adherent mucus gel was taken into account because it represents a substantial part of the secreted immunoreactive material. The empty colonic loops were weighed and the length measured $(\mathrm{cm})$. They were then homogenised for one minute in phosphate buffered saline (Ultra-Turrax; Janke and Kundel, Staufen, Germany), and stored at $-20^{\circ} \mathrm{C}$. Tissue homogenates were analysed for DNA content.

ANALYSIS OF SAMPLES

Samples of luminal contents were incubated for 24 hours with $100 \mathrm{mM}$ dithiothreitol to produce reduction and then assayed by a sandwich type ELISA as previously described. ${ }^{21}$ Briefly, the polyclonal antibody $45 \mathrm{C}$ was raised in a rabbit against rat colonic mucus glycoprotein obtained from $\mathrm{CsCl}$ gradient purified material. An immunoglobulin rich fraction was prepared using DEAE-Sephadex A50 (pH 7.2), and then used to coat ELISA plates. A part of this immunoglobulin rich fraction was also used to prepare biotinylated labelled antibody using a succinimide ester of biotin. ${ }^{21}$ Mucin content of the samples was determined from standard curves prepared from purified rat colonic mucin. The luminal contents were tested at three dilutions $(1: 4000 ; 1: 8000$, and $1: 16000$ ), each in duplicate. Samples of luminal stimulants were also assayed concurrently to verify that they did not generate false positive results in ELISA.

Colonic loop homogenates were thawed and briefly homogenised. Aliquots were sonicated for 20 seconds, and then analysed for DNA content using the fluorometric method of Hinegardner. ${ }^{22}$ The amount of mucin secreted 
from each loop was expressed as $\mu \mathrm{g}$ mucin/mg tissue DNA. Samples of luminal content were also analysed for DNA content. This analysis served as an indirect measure of tissue viability, and loops were discarded when luminal DNA content represented more than $2 \%$ of the total DNA (tissue DNA + luminal DNA). Total luminal content (fluid content + adherent mucus gel) recovered from the lumen was expressed as $\mathrm{mg}$ luminal contents/cm colonic loop.

HISTOLOGICAL ANALYSIS AND GOBLET CELI MORPHOLOGY

Histological technique

The effect of several dietary components was also monitored by histological analysis, as described previously. ${ }^{23}$ Briefly, pieces of colon $(2-2.5 \mathrm{~cm})$ taken at the end of the isolated colon experiment were fixed into Karnovsky's fixative, processed in Epon, cut into $2 \mu \mathrm{m}$ sections, stained with alcian blue ( $\mathrm{pH} 2.5$ ) followed by the periodic acid-Schiff reaction and then counterstained with haematoxylin. The alcian blue/periodic acid-Schiff method yielded a blue colour when mostly acidic mucins were present, purple when neutral mucins were also present, and magenta when mainly neutral mucins were present. The corresponding cells were designated stained mucus cells.

\section{Quantitative histology}

It is generally accepted that a reduced number of mucus cells indicates release of mucins from the colonic mucosa, and cavitation of mucus cells is the hallmark of accelerated mucus secretion. ${ }^{12425}$ Thus the extent of mucus discharge may be quantified both by assessing the number of mucus cells per crypt section and the percentage of cavitated mucus cells per preparation. For this purpose, 15-30 crypts per slide were analysed, and 500-1000 mucus cells were counted per sample of colon. A crypt was considered when it was cut along or nearly along the length of the crypt lumen (at least two thirds of the length of the crypt). Progressing from the crypt base to crypt opening, all stained mucus cells were counted on both sides of the lumen. All mucus cells were evaluated for the presence of cavitation of their apical membrane. A mucus cell with clear apical indentation into the intracellular store of mucus granules was taken as showing signs of the cavitation that accompanies recent compound exocytotic activity. Four to seven rat colons were analysed for each set of experiments. All slides were analysed by a single investigator who was blinded to the drug treatment.

\section{STATISTICAL ANALYSIS}

Data are presented as mean (SE), and compared using analysis of variance with a Bonferroni test. $\mathrm{p}<0.05$ was considered significant.
Table 1 Mucin and total luminal content of fluid after administration of non-sulphated fibres

\begin{tabular}{llcr}
\hline & $\begin{array}{l}\text { Mucin } \\
(\mu g / m g ~ D N A)\end{array}$ & $\begin{array}{l}\text { Total fluid } \\
\text { content }(\mathrm{mg} / \mathrm{cm})\end{array}$ & $n$ \\
\hline Control group & $131.9(6.5)$ & $89.7(2.3)$ & 10 \\
Alginate $(25 \mathrm{mg} / \mathrm{l})$ & $310.1(24.3)^{\star}$ & $103.3(8.8)$ & 10 \\
Pectin $(25 \mathrm{mg} / \mathrm{l})$ & $174.7(20.1)$ & $90.4(7.8)$ & 5 \\
Arabic gum $(25 \mathrm{mg} / \mathrm{l})$ & $199.9(24.4)$ & $88.7(7.4)$ & 8 \\
Cellulose $(25 \mathrm{mg} / \mathrm{l})$ & $127.3(17.2)$ & $79.9(1.21)$ & 5
\end{tabular}

Values are mean (SE). $\mathrm{n}=$ no of animals. Total fluid luminal content represents fluid content + adherent mucus gel. ${ }^{\star} \mathrm{p}<0.05$ compared with control group.

\section{Results}

EFFECT OF FIBRES ON COLONIC MUCUS SECRETION

\section{Non-sulphated fibres}

Luminal administration of sodium alginate (25 $\mathrm{mg} / \mathrm{l}$ ) in the isolated vascularly perfused rat colon induced colonic mucin release (310.1 (24.3) $\mu \mathrm{g} / \mathrm{mg}$ DNA $(\mathrm{n}=10)$ v 131.9 (6.5) $\mu \mathrm{g} / \mathrm{mg}$ DNA for the control group ( $\mathrm{n}=10$ ) $\mathrm{p}<0.05)$. Histological analysis disclosed that colonic preparations exposed to $25 \mathrm{mg} / \mathrm{l}$ sodium alginate for 30 minutes exhibited numerous cavitated goblet cells (28.7 (4.4)\% of cavitated mucus cells $(\mathrm{n}=6) v 10.6(2.4) \%$ of cavitated mucus cells for the control group $(n=6) p<0.05)$. In contrast, sodium alginate did not modify the number of stained mucus cells per crypt: $26.2(0.6)$ mucus cells per crypt v 29.8 (0.6) mucus cells per crypt for the control group $(n=6)$. Stimulation with 1 or 10 $\mathrm{mg} / \mathrm{l}$ sodium alginate did not elicit mucus discharge (175.2 (21.9) $\mu \mathrm{g} / \mathrm{mg}$ DNA $(\mathrm{n}=5)$ and $190.2(14.8) \mu \mathrm{g} / \mathrm{mg}$ DNA $(\mathrm{n}=6)$ respectively).

Compared with sodium alginate, luminal administration of pectin, gum arabic, or cellulose $(25 \mathrm{mg} / \mathrm{l})$ did not induce significant release of mucins (table 1). Even at final concentrations of up to $10 \mathrm{~g} / \mathrm{l}$, pectin and cellulose did not significantly stimulate the discharge of mucus (152.1 (4.6) $\mu \mathrm{g} / \mathrm{mg}$ DNA $(\mathrm{n}=5)$ and $120.5(33.1) \mu \mathrm{g} / \mathrm{mg}$ DNA $(\mathrm{n}=6)$ respectively). High concentrations of gum arabic were not used because of the high viscosity of the resulting mixture.

\section{Sulphated polymers}

Intracolonic administration of ulvan $(25 \mathrm{mg} / \mathrm{l})$, a sulphated algal polysaccharide, produced a sharp rise in the discharge of immunoreactive

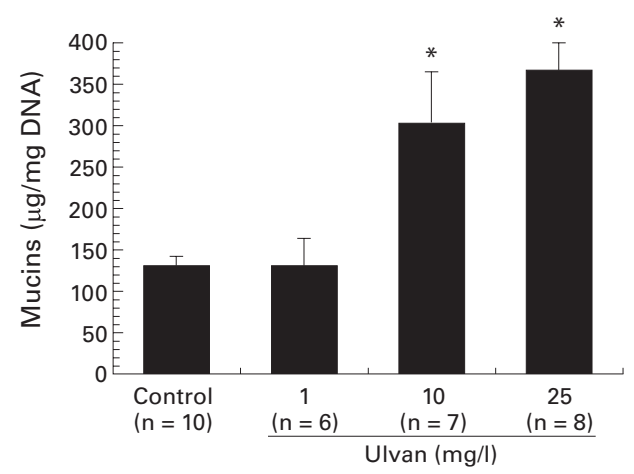

Figure 1 Colonic mucin-like immunoreactivity $(\mu \mathrm{g} / \mathrm{mg}$ $D N A$ ) to luminal administration of increasing amounts of ulvan in the isolated perfused rat colon. The secretion of mucin was evaluated by a sandwich ELISA as described in Materials and methods. Data are mean (SE). ${ }^{\star} p<0.05 v$ controls. 
Table 2 Quantitative histology, ELISA, and total fluid luminal content after administration of several algal sulphated polymers $(25 \mathrm{mg} / \mathrm{l})$

\begin{tabular}{|c|c|c|c|c|c|c|}
\hline & $\begin{array}{l}\text { Percent of } \\
\text { cavitated } \\
\text { mucus cells }\end{array}$ & $\begin{array}{l}\text { Number of } \\
\text { mucus } \\
\text { cells/crypt }\end{array}$ & $n$ & $\begin{array}{l}\text { Mucin } \\
(\mu g / m g D N A)\end{array}$ & $\begin{array}{l}\text { Total fluid } \\
\text { content }(\mathrm{mg} / \mathrm{cm})\end{array}$ & $n$ \\
\hline Control group & $10.6(2.4)$ & $29.8(1.6)$ & 6 & $131.9(6.5)$ & $89.7(2.3)$ & 10 \\
\hline Ulvan & $29.9(2.0)^{\star}$ & $30.3(1.0)$ & 6 & $367.3(32.7)^{\star}$ & $113.5(5.6)$ & 8 \\
\hline Fucoidan & $14.8(2.1)$ & $32.2(1.1)$ & 5 & $254.3(30.2)$ & $107.8(12.7)$ & 6 \\
\hline Carrageenan iota & $13.8(2.9)$ & $30.7(1.5)$ & 5 & $179.4(22.1)$ & $101.8(12.7)$ & 6 \\
\hline Carrageenan kappa & $12.4(1.7)$ & $28.9(2.2)$ & 4 & $135.3(35.1)$ & $140.4(13.1)^{\star}$ & 5 \\
\hline Carrageenan lambda & $14.1(2.3)$ & $30.5(1.4)$ & 4 & $162.8(37.5)$ & $123.5(14.3)^{\star}$ & 5 \\
\hline
\end{tabular}

Values are mean (SE). $\mathrm{n}=$ no of animals.

${ }^{\star} \mathrm{p}<0.05$ compared with control group.

material (fig 1). This mucin discharge was associated with a rise in the percentage of cavitated mucus cells (table 2, fig 2). As shown in fig 1 , the effect of ulvan was concentration dependent over the range $1-25 \mathrm{mg} / \mathrm{l}$. The first significant response was obtained with $10 \mathrm{mg} / 1$ ulvan. In contrast, ulvan did not elicit any significant increase in total fluid luminal content (table 2).

Fucoidan (25 mg/l), another sulphated polymer, showed a tendency to increase mucin secretion (254.3 (30.2) $\mu \mathrm{g} / \mathrm{mg}$ DNA, $\mathrm{n}=6$ ) although this increase did not achieve statistical significance (table 2).
Undegraded iota, kappa, and lambda carrageenans, which are used as alimentary additives (gelling agents), contain one, two, or three $\mathrm{SO}_{4}{ }^{2-}$ groups respectively. ${ }^{10}$ Undegraded iota, kappa, and lambda carrageenans at final concentrations of up to $25 \mathrm{mg} / 1$ did not produce any discharge of mucin whereas a significant increase in total luminal content of fluid was observed with the kappa and lambda carrageenans (table 2).

\section{Uronic acids}

As outlined in fig 3, luminal administration of $25 \mathrm{mg} / \mathrm{l}$ glucuronic acid (one of the major constituents of ulvan) produced a sharp rise in the secretion of mucin (376.5 (45.6) $\mu \mathrm{g} / \mathrm{mg}$ DNA $(\mathrm{n}=6) v 115.2(7.2) \mu \mathrm{g} / \mathrm{mg}(\mathrm{n}=8)$ for the control group, $\mathrm{p}<0.05$; fig $3 \mathrm{~A}$ ). Numerous goblet cells became cavitated after 30 minutes of $25 \mathrm{mg} / \mathrm{l}$ glucuronic acid stimulation (fig 3B). On stimulation with $25 \mathrm{mg} / 1$ galacturonic acid, the rise in mucin release was less pronounced (247.1 (22.8) $\mu \mathrm{g} / \mathrm{ml} \mathrm{DNA;} \mathrm{n}=6, \mathrm{p}<0.05$; fig 3A). Morphological analysis indicated that galacturonic acid tended to increase the percentage of cavitated mucus cells, although this value did not reach statistical significance (fig 3B).
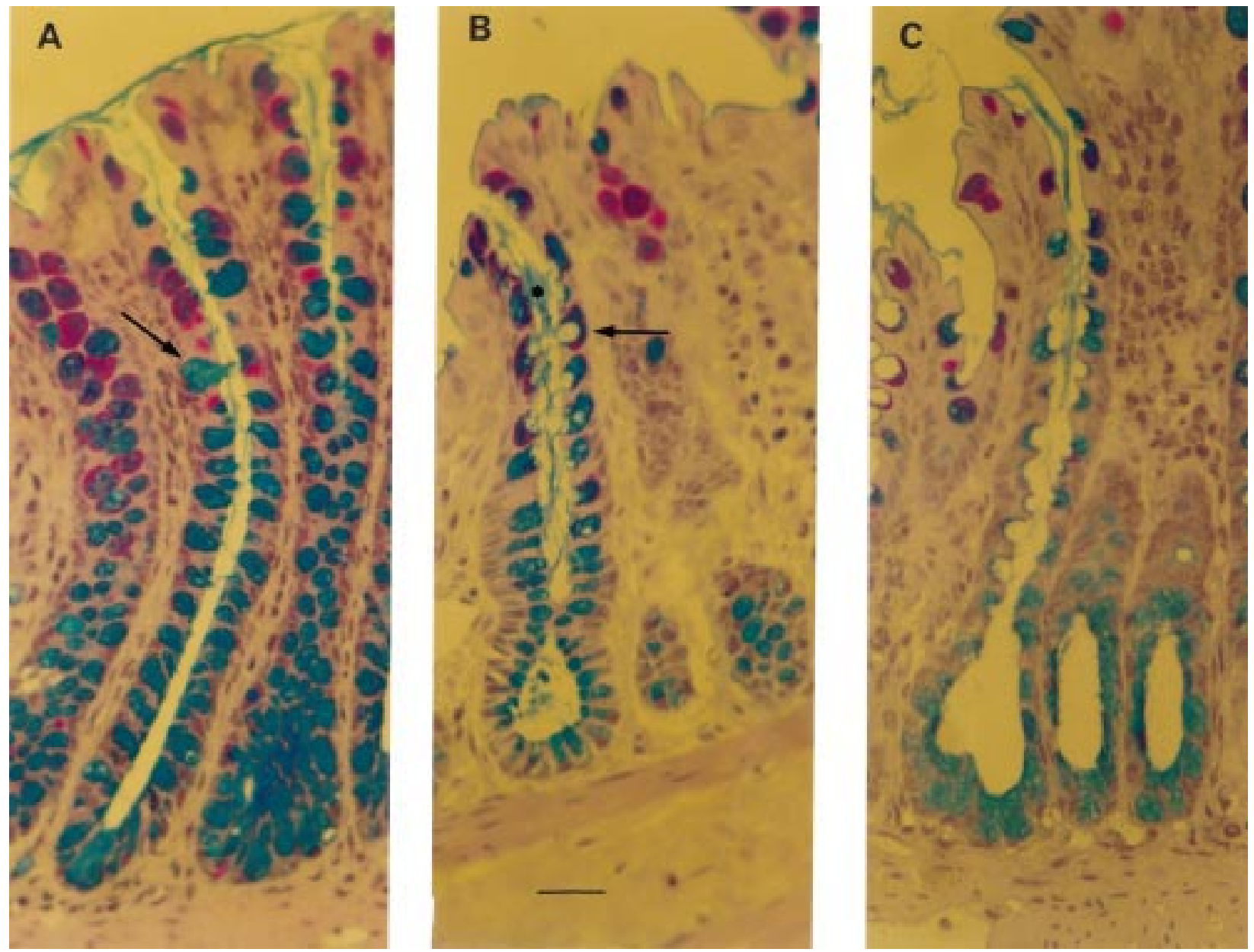

Figure 2 Thin section histology of perfused rat colon. Bar $=10 \mu \mathrm{m}$. (A) Crypt of a control preparation. This colonic loop underwent a 10 minute equilibration period, followed by a 30 minute period during which $1 \mathrm{ml}$ isotonic saline was administered to the lumen of the colonic loop. Goblet cells (alcian blue/periodic acid-Schiff stained) are filled with mucus. Arrows indicate examples of stained mucus cells. (B) Colonic crypt after administration of ulvan (25 mgll) for 30 minutes. Stained mucus cells exhibit deep apical membrane cavitation (arrow) from which streams of stained mucus (asterisk) emerged to join the mucus blanket in the crypt lumen. (C) Crypt of perfused rat colon after 30 minutes of stimulation with 5 mM butyrate. Numerous mucus cells with deep cavitation of the apical surface are easily observed. 

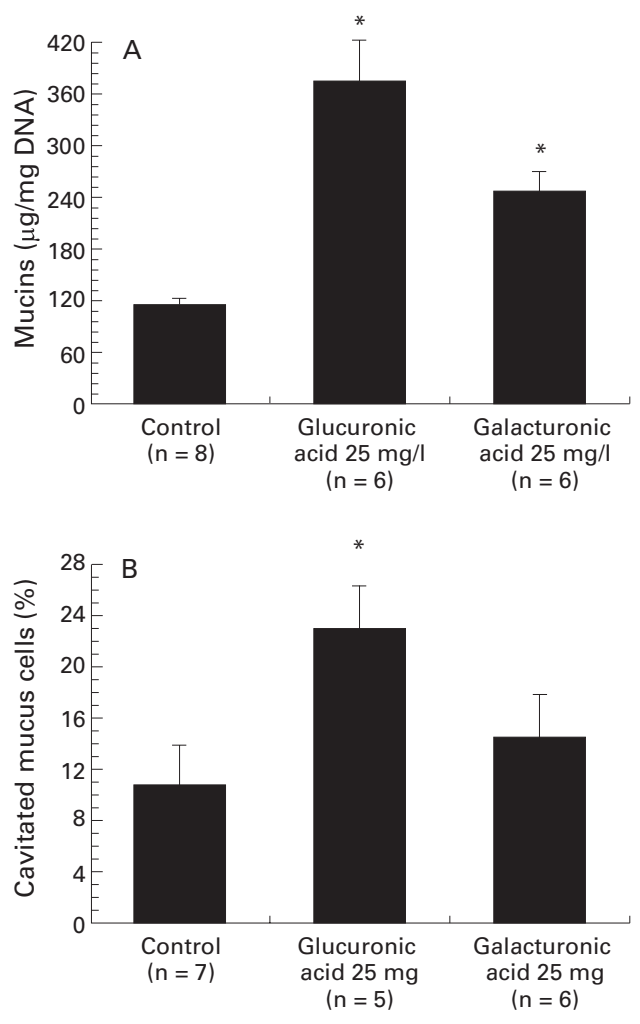

Figure 3 Effects of two uronic acids on colonic mucus cells. (A) Effects of glucuronic acid $(25 \mathrm{mg} / \mathrm{l})$ and galacturonic acid $(25 \mathrm{mg} / \mathrm{l})$ on luminal mucin secretion in the isolated vascularly perfused rat colon. ${ }^{\star} p<0.05 v$ the control group. (B) Effects of glucuronic acid $(25 \mathrm{mg} / \mathrm{l})$ and galacturonic acid $(25 \mathrm{mg} / \mathrm{l})$ on the percentage of cavitated mucus cells. The colonic mucosa was analysed by light microscopy as described in Materials and methods. Some 500-1000 stained mucus cells per slide were evaluated for the presence of apical membrane cavitation. A mucus cell with clear apical indentation into the intracellular store was taken as showing signs of cavitation. Data are mean $(S E) .{ }^{\star} p<0.05$ compared with the control group.

RELEASE OF COLONIC MUCIN BY FACTORS PRODUCED BY THE COLONIC MICROFLORA Short chain fatty acids

Luminal administration of $n$-butyrate ( $5 \mathrm{mM}$ ) provoked a significant mucin discharge (338.1 (63.6) $\mu \mathrm{g} / \mathrm{mg}$ DNA, $\mathrm{n}=9, \mathrm{p}<0.05 v 144.7$ (13.5) $\mu \mathrm{g} / \mathrm{mg}$ DNA for the control group, $\mathrm{n}=$ $9, \mathrm{p}<0.05)$. Increasing the concentration of $n$-butyrate to $100 \mathrm{mM}$ decreased the mucus response (fig 4A). Compared with control loops, the mucus cells of colonic preparations exposed to $5 \mathrm{mM}$ butyrate for 30 minutes exhibited deep apical membrane cavitation (fig 2 and fig 4B). In contrast, luminal administration of $5 \mathrm{mM} n$-butyrate failed to elicit any significant modification in the number of stained mucus cells per crypt (table 3 ).

As shown in table 3 , administration of $5 \mathrm{mM}$ acetate was without effect on mucus discharge whereas mucus secretion was observed when $100 \mathrm{mM}$ acetate was administered. On administration of $100 \mathrm{mM}$ acetate, an increase in the number of mucus cells with apical cavitation was observed (table 3). Neither 5 nor $100 \mathrm{mM}$ propionate elicited any significant discharge of mucus (table 3).
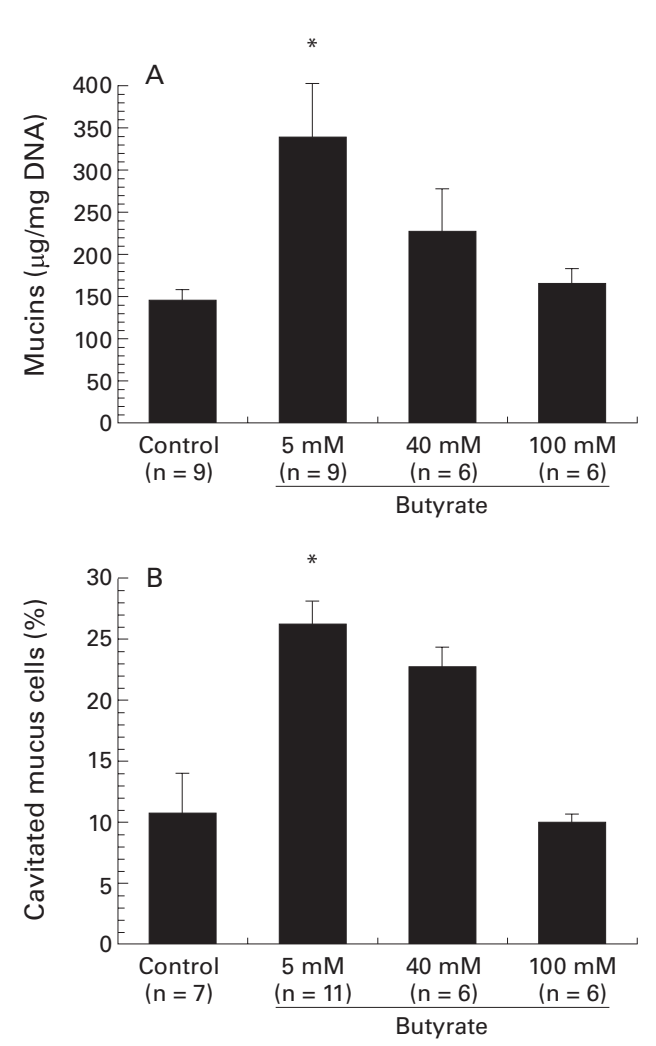

Figure 4 Effects of increasing the concentration of butyrate on colonic mucin secretion as evaluated by using a sandwich enzyme linked immunosorbent assay and by histological analysis. Data are mean (SE). ${ }^{\star} p<0.05 \mathrm{v}$ the control group.

\section{Sulphur compounds}

Mercaptides (sodium hydrogen sulphide) and mercapto fatty acids (mercaptoacetate) are readily produced by colonic bacteria from sulphated polysaccharides, cruciferous vegetables, sulphates, and dietary amino acids. ${ }^{15}$ Luminal administration of sodium hydrogen sulphide $(40 \mathrm{mM})$ or sodium mercaptoacetate $(40 \mathrm{mM})$ in the isolated vascularly perfused rat colon elicited only a modest increase in mucus secretion (table 4). Table 4 shows total luminal contents in response to sulphur compounds. Sodium hydrogen sulphide produced a twofold increase in total luminal content recovered from the lumen, although luminal DNA content was similar to that observed in the control group (data not shown).

\section{EFFECT OF DIETARY PHENOLIC COMPOUNDS ON}

MUCIN DISCHARGE

Numerous polyphenols are widely distributed in higher plants and are ingested by humans with regular food. These include trihydroxystilbene (resveratrol) and flavonoids (epicatechin, quercetin). ${ }^{26}$ Resveratrol, epicatechin, and quercetin at concentrations up to $20 \mathrm{mM}$ were all unable to induce any significant increase in colonic mucus secretion (120.5 (14.7) $\mu \mathrm{g} / \mathrm{mg}$ DNA, $\mathrm{n}=5,112.9$ (7.5) $\mu \mathrm{g} / \mathrm{mg}$ DNA, $\mathrm{n}=7$, and 135.4 (15.1) $\mu \mathrm{g} / \mathrm{mg}$ DNA, $\mathrm{n}=5$ respectively $v 110.1$ (17.2) $\mu \mathrm{g} / \mathrm{mg}$ DNA for the control group, $\mathrm{n}=6$ ). 
Table 3 Quantitative histological examination and ELISA of isolated vascularly perfused rat colon after luminal administration of short chain fatty acids

\begin{tabular}{llllll}
\hline & $\begin{array}{l}\text { Percent of } \\
\text { cavitated } \\
\text { mucus cells }\end{array}$ & $\begin{array}{l}\text { Number of } \\
\text { mucus cells/crypt }\end{array}$ & $n$ & $\begin{array}{l}\text { Mucin } \\
(\mu \mathrm{g} / m g \text { DNA) }\end{array}$ & $n$ \\
\hline Control group & $11.9(2.8)$ & $30.1(1.5)$ & 7 & $144.7(13.4)$ & 9 \\
Butyrate $5 \mathrm{mM}$ & $26.1(2.0)^{\star}$ & $29.5(1.2)$ & 11 & $338.1(63.6)^{\star}$ & 9 \\
Butyrate $100 \mathrm{mM}$ & $9.8(0.7)$ & $31.3(0.6)$ & 6 & $164.6(17.7)$ & 6 \\
Propionate $5 \mathrm{mM}$ & $16.7(2.3)$ & $31.2(1.4)$ & 5 & $190.3(28.3)$ & 6 \\
Propionate $100 \mathrm{mM}$ & $16.6(4.8)$ & $28.4(1.0)$ & 5 & $215.3(30.1)$ & 6 \\
Acetate $5 \mathrm{mM}$ & $16.2(5.3)$ & $32.5(1.1)$ & 6 & $176.9(40.2)$ & 6 \\
Acetate $100 \mathrm{mM}$ & $26.9(4.8)^{\star}$ & $32.4(0.7)$ & 8 & $381.3(50.6)^{\star}$ & 6 \\
\hline
\end{tabular}

Values are mean (SE); $\mathrm{n}=$ no of animals. Cavitation of mucus cells is the hallmark of accelerated mucus discharge by a process of compound exocytosis.

${ }^{\star} \mathrm{p}<0.05$ compared with control group.

Table 4 Mucin and total fluid luminal content after administration of reducing sulphur compounds normally present in colonic luminal content

\begin{tabular}{lllc}
\hline & $\begin{array}{l}\text { Mucin } \\
(\mu \mathrm{g} / \mathrm{mg} \mathrm{DNA})\end{array}$ & $\begin{array}{l}\text { Total fluid content } \\
(\mathrm{mg} / \mathrm{cm})\end{array}$ & $n$ \\
\hline Control group & $102.2(7.6)$ & $93.0(2.2)$ & 5 \\
Sodium mercaptoacetate $(40 \mathrm{mM})$ & $148.4(27.1)$ & $113.1(5.0)$ & 5 \\
Sodium hydrogen sulphide $(40 \mathrm{mM})$ & $132.7(13.1)$ & $223.1(11.2)^{\star}$ & 5
\end{tabular}

Values are mean (SE). $\mathrm{n}=$ no of animals

${ }^{\star} \mathrm{p}<0.05$ compared with control group.

\section{Discussion}

The mechanisms responsible for the secretion of colonic mucins are still unclear. In particular, little is known about the discharge of mucin in response to luminal factors. The preparation of isolated vascularly perfused rat colon was then used as a relevant model to analyse the changes in colonic mucin secretion in response to dietary compounds (algal fibres, dietary fibres, short chain fatty acids, sulphides, phenolic compounds).

Previous investigations suggested that dietary supplementation with fibres may modify the composition of mucin ${ }^{27}$ or the number of goblet cells. ${ }^{28}$ Such hypotheses received support from in vivo studies in various animals. Indeed, Vahouny and colleagues ${ }^{7}$ and Schnee-

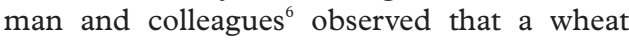
bran-containing diet increased incorporation of $\left[{ }^{3} \mathrm{H}\right]$ glucose and $\left[{ }^{35} \mathrm{~S}\right]$ sulphate into rat intestinal glycoproteins. A morphometric study by Lundin and colleagues ${ }^{28}$ also suggested that fibre feeding raised the number of goblet cells in the small intestine of Syrian Golden Hamsters. High fibre diets also induced a rise in the number of goblet cells in rat colon. ${ }^{29} 30$ Furthermore, dietary supplementation with $10 \%$ psyllium, a highly branched arabino-xylan polysaccharide used as a fibre supplement, evoked an increase in luminal mucin levels in rat colon, suggesting a higher goblet cell secretory activity. ${ }^{9}$ In contrast, the present data show that pectin and cellulose did not induce a short term effect on mucin discharge.

An attractive hypothesis that could explain these discrepancies is that dietary fibres induce colonic mucus discharge in vivo through an indirect mechanism that is not present in our model. This mechanism could involve short chain fatty acids, which are formed in the colon by bacterial fermentation of dietary fibre. ${ }^{12} \mathrm{We}$ therefore tested the three major short chain fatty acids (acetate, propionate, and butyrate) present in the colon. We found for the first time that a physiological concentration of butyrate (5 $\mathrm{mM})$ or acetate $(100 \mathrm{mM})$ caused a threefold increase in mucus secretion in the lumen of isolated perfused rat colon, suggesting that fermentable dietary fibres may stimulate colonic mucin secretion in vivo through the production of short chain fatty acids. Moreover, Finnie and colleagues ${ }^{31}$ showed that sodium butyrate induces a striking increase in mucin synthesis by human colonic biopsy specimens. These observations suggest that short chain fatty acids are influential in increasing the synthesis and secretion of colonic mucin. If this hypothesis adequately explains modulation of mucus secretion by dietary fibres, other mechanisms are also possible. These may include physical characteristics of colonic content, viscosity properties, modification of nutrient absorption, and indirect effects through hormonal regulation.

In this study, $5 \mathrm{mM}$ butyrate produced colonic mucus secretion whereas the highest concentrations of butyrate $(100 \mathrm{mM})$ resulted in a lower mucus response. This result agrees with earlier observations showing that the maximal effect of butyrate on the colonic secretion of the hormonal peptide PYY was observed around $5-10 \mathrm{mM} .^{32}{ }^{33} \mathrm{On}$ the basis of these data, it may be speculated that $100 \mathrm{mM}$ butyrate induces the secretion of some inhibitory factors of colonic secretions. Somatostatin appears to be a good candidate, as endocrine $\mathrm{D}$ cells are scattered throughout the epithelium of distal bowel and it inhibits exocrine and endocrine secretions in the gut. ${ }^{34}$ Additional experiments with the isolated perfused rat colon are required to validate this hypothesis.

In response to stimulation, intestinal goblet cells may accelerate their discharge of mucin by way of two processes. In many mucus cells, a phenomenon of compound exocytosis is induced, resulting in deep cavitation of the apical membrane surface of mucus cells. ${ }^{125}$ Some intestinal mucus cells can also respond to stimulation by another process that decreases the intracellular store of mucus granules but without cavitation. ${ }^{125}$ When the latter mechanism leads to total depletion of mucus granules, goblet cells are no longer stained by alcian blue/periodic acid-Schiff and appear indistinguishable from other epithelial cells. This study shows for the first time that luminal acetate and butyrate induce mucus discharge by compound exocytosis. Supporting this hypothesis, the results of Sakata and Engelhardt ${ }^{24}$ and ours showed that short chain fatty acids did not significantly influence the number of mucus cells staining for mucin.

Our interest focused then on algal polysaccharides because of the widespread use of some of these fibres (alginate, carrageenans) by food manufacturers as gelling agents, thickeners, stabilisers, or emulsifiers. ${ }^{10}$ The doses (1-25 $\mathrm{mg} / \mathrm{l}$ ) of algal fibres used in this study were chosen to approximate the estimated human intake as food additive. ${ }^{35}$ The present data show for the first time that alginate $(25 \mathrm{mg} / \mathrm{l})$ appreciably increased the discharge of colonic mucin. Interestingly, the magnitude of mucus release stimulated by alginate was only threefold less than that stimulated by bethanechol (a cholinergic agonist) or the neuropeptide 
bombesin, which were the most powerful agents used in our earlier study. ${ }^{21}$ Together, these data indicate that alginate is an effective secretagogue of colonic mucus, suggesting its potential therapeutic usefulness in dietary supplementation. However, the physiological consequences of alginate ingestion are far from being understood and may require in particular long term studies. Indeed, changes in dietary habits may modify the chemical composition and functional characteristics of mucins. ${ }^{5}{ }^{737}$

Ulvan, a fibre extracted from green seaweed, has a high content of sulphate and glucuronate moieties. ${ }^{10}$ Our results establish for the first time that ulvan induces mucin secretion. Interestingly, glucuronic acid was also found to stimulate mucus discharge, suggesting that this substrate may be essential for mucus secretory activity. These studies also show that two other sulphated polysaccharides (carrageenin and fucoidan) did not induce a significant increase in mucus secretion. The presence of sulphated groups thus does not seem to influence colonic mucin discharge significantly.

A consequence of the presence of sulphated polysaccharides is the production of sulphide in the colonic lumen. ${ }^{16}$ Luminal concentrations of sulphides in humans vary between 0.1 and 10 $\mathrm{mM} .{ }^{15}$ In this study, we found that supraphysiological doses of two sulphides did not stimulate mucin discharge. Nonetheless, it should be pointed out that sodium hydrogen sulphide provoked a sharp increase in luminal fluid accumulation whereas sodium mercaptoacetate was without effect. These results agree with early observations that hydrogen sulphide, but not mercaptoacetate, inhibited sodium transport in the colonic mucosa. ${ }^{38}$

In conclusion, we have provided evidence that the preparation of isolated vascularly perfused rat colon offers a unique ex vivo model for assessing the quantitative changes in mucin secretory activity of colonic goblet cells in response to well defined luminal factors. This approach has enabled us to show that some dietary fibres (alginate, ulvan), uronic acids (glucuronic acid, galacturonic acid), and short chain fatty acids may be useful for stimulating colonic mucus secretion. Our findings could be of considerable interest in gastrointestinal physiology and nutrition. They need to be supported by additional studies with in vivo and in vitro models to validate the hypothesis that some dietary fibres and short chain fatty acids may be protective against various intestinal diseases.

1 Specian RD, Oliver MG. Functional biology of intestinal goblet cells. Am f Physiol 1991;260:C183-93.

2 Forstner JF, Forstner GG. Gastrointestinal mucus. In: Johnson LR, ed. Physiology of the gastrointestinal tract. 3rd ed. son LR, ed. Physiology of the gastrointes
New York: Raven press, 1994:1255-83.

3 Rhodes JM. Colonic mucus and mucosal glycoproteins: the key to colitis and cancer? Gut 1989;30:1660-6.

4 Smith AC, Podolsky DK. Colonic mucin glycoproteins in health and disease. Clin Gastroenterol 1986;15:815-37.

5 Cassidy MM, Lightfoot FG, Grau L, et al. Effect of chronic intact of dietary fibers on the ultrastructural topography of rat jejunum and colon: a scanning electron microscopy study. Am $\mathcal{F}$ Clin Nutr 1981;34:218-28.

6 Schneeman BO, Richter BD, Jacobs LR. Response to dietary wheat bran in the exocrine pancreas and intestine of rats. F Nutr 1982;112:283-6.

7 Vahouny GV, Le T, Ifrim I, et al. Stimulation of intestinal cytokinetics and mucins turnover in rats fed wheat bran or cellulose. Am f Clin Nutr 1985;41:895-900.
8 Satchithanandam S, Vargofcak-Apker M, Calvert RJ, et al. Alteration of gastrointestinal mucin by fiber feeding rats. $\mathcal{F}$ Nutr 1990; 120: 1179-84.

9 Satchithanandam S, Klurfeld DM, Calvert RJ, et al. Effects of dietary fibers on gastrointestinal mucin in rats. Nutr. Res. 1996;16:1163-77.

10 Michel C, Macfarlane GT. Digestive fates of soluble polysaccharides from marine macroalgae: involvement of colonic microflora and physiological consequences for the host. F Appl Bacteriol 1996;80:349-69.

11 Boisson-Vidal C, Haroun F, Ellouali M, et al. Biological activities of polysaccharides from marine algae. Drugs of the Future 1995;20:1237-49.

12 Scheppach W. Effects of short chain fatty acids on gut morphology and function. Gut 1994;35 (suppl 1):S35-8.

13 Butzner JD, Parma R, Bell CJ, et al. Butyrate enema therapy stimulates mucosal repair in experimental colitis in the rat. Gut 1996;38:568-73.

14 Cook SI, Sellin JH. Short chain fatty acids in health and disease. Aliment Pharmacol Ther 1998;12:499-507.

15 Roediger WEW, Duncan A, Kapaniris O, et al. Reducing sulfur compounds of the colon impair colonocyte nutrition: mplications for ulcerative colitis. Gastroenterology 1993; 104:802-9.

16 Roediger WEW, Moore J, Babidge W. Colonic sulfide in pathogenesis and treatment of ulcerative colitis. Dig Dis Sci 1997;42:1571-9.

17 Hertog MGL, Hollman PCH. Potential effects of dietary flavonol quercetin. Eur f Clin Nutr 1996;50:63-71.

18 Jang M, Cai L, Udeani GO, et al. Cancer chemopreventive activity of resveratrol, a natural product derived from grapes. Science 1997;275:218-20.

19 Yang CS, Lee M-J, Chen L, et al. Polyphenols as inhibitors of carcinogenesis. Environ Health Perspect 1997;105:971-6.

20 Plaisancié P, Bernard C, Chayvialle JA, et al. Regulation of glucagon-like peptide-1-(7-36)amide secretion by intestinal neurotransmitters and hormones in the isolated vascularly perfused rat colon. Endocrinology 1994:135:2398-403.

21 Plaisancié P, Barcelo A, Moro F, et al. Effects of neurotransmitters, gut hormones, inflammatory mediators on mucus discharge in rat colon. Am 7 Physiol 1998;275:G1073-84.

22 Hinegardner TT. An improved fluorimetric assay for DNA. Anal Biochem 1971;39:197-201.

23 Plaisancié P, Bosshard A, Meslin JC et al. Colonic mucin discharge by a cholinergic agonist, prostaglandins, peptide YY in the isolated vascularly perfused rat colon. Digestion 1997;58:168-75.

24 Sakata T, Engelhardt WV. Influence of short chain fatty acids and osmolality on mucus release in rat colon. Cell Tissue Res 1981;219:371-7.

25 Forstner GG. Signal transduction, packaging and secretion of mucins. Annu Rev Physiol 1995;57:585-605.

26 Soleas GJ, Diamandis EP, DM Goldberg. Wine as a biological fluid: history, production, role in disease prevention. $f$ Clin Lab Anal 1997;11:287-313.

27 Sharma R, Schumacher U, Ronaasen V, et al. Rat intestinal mucosal responses to a microbial flora and different diets. Gut 1995;36:209-14.

28 Lundin E, Zhang JX, Huang CB, et al. Oat bran, soybean hull increase goblet cell volume density in the small intestine of the golden hamster. A histochemical and stereologic light-microscopic study. Scand Gastroenterol 1993; 28:15-22.

29 Enss ML, Schmidt-Wittig U, Honer K, et al. Mechanical challenge causes alterations of rat colonic mucosa and released mucins. Alterations of mucosa and mucins. f Exp Anim Sci 1994;36:128-40.

$30 \mathrm{McCullough}$ JS, Ratcliffe B, Mandir N, et al. Dietary fiber and intestinal microflora: effects on intestinal morphomtry and crypt branching. Gut 1998;42:799-806.

31 Finnie IA, Dwarakanath AD, Taylor BA, et al. Colonic mucin synthesis is increased by sodium butyrate. Gut 1995;36:93-9.

32 Longo WE, Ballantyne GH, Savoca PE, et al. Short-chain fatty acid release of peptide $\mathrm{YY}$ in the isolated rabbit distal colon. Scand f Gastroenterol 1991;26:442-8.

33 Plaisancié P, Bernard C, Chayvialle JA, et al. Luminal peptide YY-releasing factors in the isolated vascularly perfused rat colon. F Endocrinol 1996;151:421-9.

34 Yamada T, Chiba T. Somatostatin. In: Handbook of Physiology. Section 6: The gastrointestinal system. Volume II: neural and endocrine biology, ed 3. Bethesda, MD: American Physiand endocrine biology, ed 3. Bethesd

35 Food and Nutrition Board. Estimating distribution of daily intakes of certain GRAS substances. Committee on GRAS list survey, Phase III. Washington, DC: Food and Nutrition Board, Division of Biological Sciences, Assembly of Life Sciences, National Research Council, National Academy of Sciences, 1976

36 Calvert J, Satchithanandam S. Effects of graded levels of high-molecular-weight carrageenan on colonic mucosal thymidine kinase activity. Nutrition 1992;8:252-7.

37 Huang CB, Lundin E, Zhang JX, et al. Dietary fibre and colonic mucin change in golden hamster. A morphometric and histochemical study. In: Southgate DAT, Waldron K, Johnson IT, et al, eds. Dietary fibre: chemical and biological aspect. Cambridge: Royal Society of Chemistry/

38 Florin T, Neate of Food Research, 1990:243-7. sulfide on isolated rat colonic epithelium. In: Goebell H, sulfide on isolated rat colonic epithelium. In: Goebell $\mathrm{H}$, Progress in basic research and clinical implications. Dordrecht: Kluwer Academic, 1991:443. 